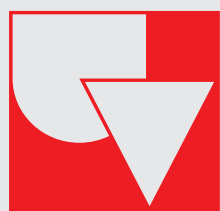

Universidad del Valle

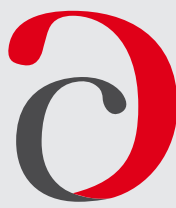

Cuadernos de Administración
Journal of Management

Print ISSN: 0120-4645 / E-ISSN: 2256-5078 / Short name: cuad.adm.

Pages: 126-142 / Vol: 36 / Issue: 67 / May - Aug. 2020

Faculty of Administration Sciences / Universidad del Valle /

Cali - Colombia

\title{
Adjustment by size effect on the cost of equity: Pending practice in capital budget in Colombia
}

\author{
Ajuste por efecto tamaño en el costo del patrimonio: \\ Práctica pendiente en el presupuesto de capital en Colombia
}

\begin{abstract}
${ }^{1}$ Walther Reina GutiérreziD
Full-time Professor, Faculty of Economic Sciences, Universidad de Antioquia, Medellín, Colombia e-mail: walter.reina@udea.edu.co
\end{abstract}

\section{Jenny Moscoso EscobariD}

Full Professor, Faculty of Economic Sciences, Universidad de Antioquia, Medellín Colombia

e-mail: jenny.moscoso@udea.edu.co

\section{${ }^{3}$ Carolina Montoya GonzálezDD}

Financial Lab Consultant, Universidad de Antioquia, Medellín, Colombia e-mail: diana.montoya11@udea.edu.co

\begin{abstract}
This research identifies and analyzes the implications of capital budgeting techniques implemented by large, medium and small companies, related to the use and calculation of the discount rate - emphasizing in the cost of equity, adjusting it with a size premium and the calculation method of the latter- differentiating between the procedure of family and non-family businesses and the types of projects. Additionally, the same procedure is used for the viability indicators of the projects given their relevance in capital budget. For this, a descriptive analysis accompanied by contingency tables is made to a group of 182 Colombian companies. The results show that (i) only $14 \%$ of SMEs that evaluate their projects (93) adjust the discount rate with a size premium, (ii) procedures to define capital budget are more informal in family companies, (iii) expansion and replacement projects are more evaluated by family businesses, while mergers and acquisitions are more evaluated by non-family businesses, and (iv) there is little transfer of knowledge from the academy to the company.
\end{abstract}

Article of Scientific and Technological Research

Submitted: 30/04/2019

Reviewed: 20/01/2020

Accepted: 07/04/2020

Thematic lines: Administration and Organizations

JEL classification: G30- G31

DOI: https://doi.org/10.25100/cdea.v36i67.7896

Keywords: Premium or size-effect, CAPM, Capital budgeting, Cost of capital, Family business, Cost of equity.

1 Economist, Universidad Autónoma Latinoamericana, Colombia, Doctor (c) in Business Management, Universidad de Valencia, Spain. Research Group in Finances (GiFi), Category B, Universidad de Antioquia, Colombia.

2 MA in Business Management, Universidad de Antioquia, Colombia, Doctor in Engineering, Industry and Organizations, Universidad Nacional, Colombia. Research Group in Finances (GiFi), Category B, Universidad de Antioquia, Colombia.

3 MA in Business Management, Universidad de Antioquia, Colombia. 


\section{Resumen}

La presente investigación identifica y analiza las implicaciones de las técnicas de presupuesto de capital implementados por las empresas grandes medianas y pequeñas, relacionadas con el uso y cálculo de la tasa de descuento - haciendo énfasis en el costo del patrimonio, el ajuste al mismo con una prima por tamaño y la forma de cálculo de esta última - diferenciando entre el procedimiento de empresas familiares y No familiares y los tipos de proyectos. Adicionalmente, se efectúa el mismo procedimiento para los indicadores de viabilidad de los proyectos dada su relevancia en el presupuesto de capital. Para ello se realiza un análisis descriptivo acompañado de tablas de contingencia a un grupo de 182 empresas colombianas. Los resultados demuestran que (i) solo el $14 \%$ de las PYMES que evalúan sus proyectos (93) ajustan la tasa de descuento con una prima por tamaño, (ii) los procedimientos para definir el presupuesto de capital son más informales en las empresas familiares, (iii) los proyectos de expansión y de reemplazo son más evaluados por las empresas familiares, mientras que las fusiones y adquisiciones son más evaluadas por las empresas No familiares (iv) hay una escasa transferencia del conocimiento de la academia a la empresa.

Palabras clave: Prima o efecto tamaño, CAPM, Costo de capital, Presupuesto de capital, Empresa familiar, Costo del patrimonio.

\section{Introduction}

Research conducted since the 1950s in the field of capital budgeting (henceforth, CB) have highlighted the significance of project evaluation and the tools used to that end (Dean, 1952; Gitman and Forrester, 1977; Arnold and Hatzopoulos, 2000; Ryan and Ryan, 2002) as this process allows budget execution to be prioritized, based on profitability, cost, and resource availability (Verbeeten, 2006).

Despite advances in the financial theory used for CB preparation such as real options, the Weighted Average Cost of Capital (WACC), the Capital Asset Pricing Model (CAPM), Beta analysis, the Internal Rate of Return (IRR), the Net Present Value (NPV), and the Investment Recovery Period (IRP), among others (Arnold and Hatzopoulos, 2000; Brounen, De Jong, and Koedijk 2004;
Verbeeten, 2006; Bennouna, Meredith, and Marchant, 2010; Maroyi and Poll, 2012; Singh, Jain, and Yadav, 2012), the procedures firms follow when preparing it evolve slowly, revealing a gap between theory and practice (Gitman and Forrester, 1977; Bennouna et al., 2010), especially in both emerging economies and some BRICS economies (Maroyi and Poll, 2012; Singh et al., 2012).

Correspondingly, until now most of the research works have focused on how large firms and / or those listed on the stock exchange carry out CB. (Gitman and Forrester, 1977; Bruner, Eades, Harris, and Higgins, 1998; Bennouna, et al., 2010; Rigopoulos, 2015), overlooking in their analysis non-listed small and medium-sized companies -which have greater difficulties when defining it. Besides, none of these works has examined whether there is a difference in the way such budgeting is carried out in family ${ }^{1}$ and nonfamily businesses (henceforth, FB and NFB ), an important aspect considering that FBs: (i) represent over $66 \%$ of all businesses worldwide, account on average for $60 \%$ of employment, and contribute on average $67 \%$ to GDP (Family Firm Institute, 2014) (ii) these companies place great value on Socioemotional Wealth (SEW), defined as those non-financial aspects that are key to these organizations (Gómez-Mejía, Haynes, Núñez-Nickel, Jacobson, and Moyano-Fuentes, 2007), which could influence how their CB is determined.

On the other hand, although researched CB-related topics include the use and calculation of the discount rate (Gitman and Forrester, 1977; Bruner, et al., 1998) and viability indicators (Gitman and Forrester, 1977; Perlitz, Peske, and Schrank, 1999, Bennouna, et al., 2010; Rigopoulos, 2015) few studies make a distinction between the CB procedures followed by firms when conducting expansion, replacement, merger and acquisitions projects, except for Brigham (1975) and Graham and Harvey (2001), where those procedures are singled out, although only for some of these types of projects.

\footnotetext{
A family business is understood as one in which there is an economic, finan cial or administrative control exercised by two or more people who are first or second degree blood relatives (e.g., father, mother or children and siblings); or legally related by adoption (e.g., father, mother, adopting person or adopted child); or married to each other (Article 6 of Regulatory Decree No. 187 of 1975).

2 Study conducted in 40 countries across the different continents (the $66 \%$ is an average resulting from all data ranging from $35 \%$ in Afghanistan and $96 \%$ in the Dominican Republic).
} 
Regarding the discount rate, several studies have investigated the rate used by firms to assess the viability of their projects (Block, 1999; Arnold and Hatzopoulos, 2000; Bennouna et al., 2010), mainly the use of the WACC and / or the cost of equity (henceforth $\mathrm{CE}$ ). However, many of those studies neither deal with how it is calculated (Block, 1999), nor inquire whether any type of adjustment is made for additional risks, for example, size (Banz, 1981; Fama and French, 1993), and if they do, they rarely look into the type of adjustment made (Bruner et al, 1998; Hermes, Smid, and Yao, 2007; Nurullah and Kengatharan, 2015).

Moreover, other research studies have generated controversies around the calculation of the CE through the CAPM, proposing either adjustments to it or none at all (Fama and French, 1992; Lessard, 1996; Damodaran, 2003; Estrada, 2007) including, for example, adjusting for size premium or size effect (Banz, 1981; Fama and French 1993, Ibbotson Associates, 2003; Asness, Franzzini, Israel, and Moskowitz, 2018). However, the methods that firms use when calculating that adjustment have been studied sparsely.

Similarly, authors such as Kengatharan (2018) raise the need to assess the influence that CFOs' knowledge, the incentive structure, the allocation of decision rights, and financial structure may have on $\mathrm{CB}$ practices, thus providing a focus for this proposal given that these aspects are covered when the differences between FB and NFB are established.

Consequently, the main aim and contribution of this research is to identify and analyze the implications of the CB techniques relating to the use and calculation of the discount rate that are implemented by large, medium, and small companies, with emphasis on the cost of equity -adjusted for size premium- and on how the latter is calculated by means of differentiating the procedure used in FB and NFB and project types.

This proposal is structured in six sections as follows: first, the introduction; second, the literature review, third, the methodology; fourth, the study results; fifth, the discussion of the result, and finally the conclusions.

\section{Literature review}

\subsection{Discount rate in capital budgeting}

$\mathrm{CB}$ is the process of identifying investment projects in order to maximize shareholder value (Dayananda, Irons, Harrison, Herbohn, and Rowland, 2002) and it is linked to investments in long-term assets (Brickley, 2006). Risk is an important factor that should be analyzed within this process (Brigham and Ehrhardt, 2002) as it is introduced by some CFOs via the discount rate (Graham and Harvey, 2001) and is calculated differently among firms due to aspects such as size, their participation in international markets and public listing.

In this respect, studies conducted in large and small companies in the United States show the progress in the use of techniques such as the CAPM, going from $6 \%$ to 73.5 $\%$ in a 26-year span (Brigham 1975; Bruner et al.,1998; Block 1999; Graham and Harvey, 2001). Conversely, Arnold and Hatzopulos (2000) noted in their study involving 300 companies from the United Kingdom that only $16 \%$ of large companies and $8 \%$ of medium-sized companies use the CAPM as a discount rate, while Brounen et al. (2004) indicate it is used by only $55.6 \%$ of the firms surveyed in the Netherlands, and it is not as widely used in other countries. A similar picture emerges in China, where according to Hermes et al. (2007), $65 \%$ of 300 listed and unlisted companies use it.

In the case of emerging economies and some BRICS, the use of stylized techniques for calculating the discount rate is also limited. According to Batra and Verma (2017), only $33 \%$ of 500 companies listed on the stock market use the CAPM, akin to Maquieira, Preve, and Sarria-Allende (2012), who concluded in their study that only $38 \%$ of companies use it.

Despite progress on the use of the CAPM in some economies, the same is not true for adjustments made to it on account of additional risks. In the case of size premium adjustment, although the model has been criticized since Banz (1981), research on it has been scarce. For example, Graham and Harvey (2001) found size adjustments are made by $14.57 \%$ 


\begin{tabular}{|c|c|c|c|c|c|}
\hline Author & Unit of analysis & Country & $\begin{array}{l}\text { \% of the sample } \\
\text { that uses CAPM }\end{array}$ & $\begin{array}{l}\% \text { of the sample } \\
\text { that makes risk } \\
\text { adjustments to } \\
\text { the CAPM }\end{array}$ & $\begin{array}{c}\text { \% of the sample } \\
\text { that adjusts } \\
\text { CAPM for size } \\
\text { premium }\end{array}$ \\
\hline $\begin{array}{l}\text { Bruner et al. } \\
\text { (1998) }\end{array}$ & $\begin{array}{c}27 \text { high-prestige } \\
\text { corporations, } 10 \\
\text { financial advising } \\
\text { leaders }\end{array}$ & USA & $\begin{array}{l}81 \text { of firms and } \\
80 \text { advisors }\end{array}$ & $\begin{array}{l}26 \text { firms, } \\
0 \text { of financial } \\
\text { advisors }\end{array}$ & N/A \\
\hline $\begin{array}{c}\text { Graham \& Harvey } \\
\qquad(2001)\end{array}$ & $\begin{array}{l}392 \text { financial } \\
\text { managers of main } \\
\text { large and small } \\
\text { firms }\end{array}$ & USA & 73.5 & 34.29 & 14.57 \\
\hline $\begin{array}{l}\text { Brounen et al. } \\
\quad(2004)\end{array}$ & $\begin{array}{l}313 \text { large and small } \\
\text { public and privately } \\
\text { owned firms }\end{array}$ & $\begin{array}{l}\text { UK, The } \\
\text { Netherlands, } \\
\text { Germany and } \\
\text { France }\end{array}$ & $\begin{array}{c}47.1 \text { in UK, } \\
55,6 \text { in The } \\
\text { Netherlands, } \\
34 \text { in Germany and } \\
45.2 \text { in France }\end{array}$ & $\begin{array}{l}27.3 \text { in UK, } 15.4 \text { in } \\
\text { The Netherlands, } \\
16.1 \text { in Germany } \\
\text { and } 30.3 \text { in France }\end{array}$ & $\begin{array}{l}\text { 21.88\% in UK, } \\
17.02 \% \text { in The } \\
\text { Netherlands, } \\
\text { 9.91\% in Germany } \\
\text { and } 23.64 \% \text { in } \\
\text { France }\end{array}$ \\
\hline $\begin{array}{l}\text { Maquieira et al. } \\
\text { (2012) }\end{array}$ & $\begin{array}{l}290 \text { small and } \\
\text { medium-sized non- } \\
\text { listed firms from } \\
\text { Latin America }\end{array}$ & $\begin{array}{c}\text { Argentina, } \\
\text { Chile, Colombia, } \\
\text { Ecuador, Peru, } \\
\text { Uruguay, } \\
\text { Venezuela and } \\
\text { others }\end{array}$ & 38 & 24.6 & N/A \\
\hline $\begin{array}{l}\text { Hanaeda \& Serita } \\
\qquad(2014)\end{array}$ & $\begin{array}{l}214 \text { small and large } \\
\text { firms from Japan } \\
\text { stock market }\end{array}$ & Japan & 49.4 & 8.6 & N/A \\
\hline \multicolumn{6}{|c|}{ Note. N/A indicates the studies were not queried for adjustment by size premium. } \\
\hline \multicolumn{6}{|c|}{ Source: Authors' own elaboration. } \\
\hline
\end{tabular}

of firms, a fact later confirmed by Brounen et al. (2004), who indicated said adjustment is carried out in the countries studied and is greater than that made by American firms. This reality shows that size adjustment to the CAPM not only pertains to small companies in emerging economies (Table 1).

\subsection{Cost of equity from CAPM in asset valuation}

Sharpe's (1964) CAPM model is one of the most used to determine CE (Bruner, et al., 1998; Pereiro and Galli, 2000; Brounen, et al., 2004; Nurullah and Kengatharan, 2015). However, several authors have raised a series of criticisms of this model. For instance, Banz (1981) pointed out additional important factors for determining the price of the expected return and the market risk of an asset are not considered by the model in proposing a simple linear relationship between them; he also argued market inefficiency can lead to an incorrect model specification. On the other hand, Fama and French (1992) point out that asset returns are not adequately explained by Beta while Dickson and Giglierano (1986) argue it cannot be used in new ventures because the information from the statistical distribution of returns is not available a priori. Based on the criticisms, a series of models derived from the original CAPM are proposed, adding a country risk premium (Damodaran, 2003), different unsystematic risks such as shareholding, illiquidity and size (Pereiro and Galli, 2000) or incorporating Beta adjustments (Lessard, 1996; Estrada, 2007).

Regarding size, studies applied in emerging and developed economies show the existence of a size effect, considered in the asset valuation models (Asness, et al., 2018) currently developed (for example, Fama and French, 2015). In this sense, Banz's (1981) findings acknowledge it, highlighting that the NYSE-listed stocks with the smallest capitalization obtain higher average returns than stocks with the largest capitalization. 
Walther Reina Gutiérrez et al. ::

Table 2. Some studies that evidence the effect of size in asset valuation

\begin{tabular}{|c|c|c|c|}
\hline Author & $\begin{array}{c}\text { Period } \\
\text { of analysis }\end{array}$ & Market & Value of size premium \\
\hline \multicolumn{4}{|l|}{ Developed markets } \\
\hline Banz (1981) & $1936-1975$ & Firms in NYSE & $1.52 \%$ month \\
\hline Chan et al. (1985) & 1958-1977 & Firms in NYSE & $12 \%$ year \\
\hline Rubio (1988) & 1963-1982 & Firms in Spain Stock Exchange & $3.2 \%$ month \\
\hline Fama \& French (1993) & 1963 and 1990 & Firms in NYSE-AMEX-NASDAQ & $0.46 \%$ month \\
\hline Ibbotson Associates (2003) & $1926-2002$ & Firms in NYSE, AMEX, NASDAQ & $3.7 \%-9.6 \%$ \\
\hline Van Dijk, (2011) & $\begin{array}{l}30 \text { years after } \\
1981\end{array}$ & Literature review & $\begin{array}{l}\text { It is premature to indicate that } \\
\text { size effect disappeared }\end{array}$ \\
\hline Hou \& van Dijk, (2018) & $1963-2014$ & Firms in NYSE-AMEX-NASDAQ & $\begin{array}{c}\text { 1963-1982: } 10 \% \text { year. } \\
\text { 1983-2014: } 0.68 \% \text { a } 0.74 \% \text { month }\end{array}$ \\
\hline Asness et al. (2018) & $1926-2012$ & $\begin{array}{l}30 \text { industries from the USA and } 24 \\
\text { international capital markets }\end{array}$ & $\begin{array}{l}0.42 \% \text { for profitability, } 0.35 \%- \\
0.44 \% \text { for security or payment } \\
\text { and } 0.20 \% \text { for growth. }\end{array}$ \\
\hline \multicolumn{4}{|l|}{ Emerging markets } \\
\hline Fama \& French (1998) & 1987-1995 & 16 emerging markets & $8.7 \%$ to $14.89 \%$ \\
\hline Rouwenhorst (1999) & 1990-1999 & 20 emerging markets & $0.69 \%$ to $0.7 \%$ \\
\hline Pereiro \& Galli (2000) & 1993-1998 & $\begin{array}{c}\text { Firms and consultants from } \\
\text { Argentina }\end{array}$ & $15.8 \%$ year \\
\hline $\begin{array}{c}\text { Barry, Goldreyer, Lockwood, \& } \\
\text { Rodríguez (2002) }\end{array}$ & $1985-2000$ & 35 emerging markets & $30 \%$ annualized \\
\hline
\end{tabular}

Chan, Chen, and Hsieh (1985) also confirmed it in the same market as well as Fama and French (1993) in NYSE, NASDAQ and AMEX through their three-factor model. This situation is corroborated in turn by Ibbotson Associates (2003), who found in their study a size premium ranging between $3.7 \%$ and 9.6 $\%$. This effect was also identified by Rubio (1988) with a monthly $3.2 \%$ in Spanish stocks. Finally, more recent studies in the United States and various developed economies in Europe continue to claim that the size premium exists and that it is significant and positive (van Dijk, 2011; Hou and van Dijk, 2018; Asness et al., 2018).

In emerging markets, Fama and French (1998) found a size effect on portfolio returns with equal and different weight in 11 of the 16 countries in their sample. In turn, Rouwenhorst (1999) identifies the presence of a size premium in 7 of the 20 emerging countries that are part of his study, when the assets and the percentage of investment in the countries are equal. Pereiro and Galli (2000) proposed a model of stackable premiums and adjustments built from the CAPM in which a size discount was included, obtaining a 15.8 $\%$ premium in Argentina (Table 2).

\subsection{Indicators to assess project viability}

Although by the end of the 1970s the use of indicators such as the IRP ranked first among small businesses in the USA (Block, 1977), it is evident that this reality changed in such a way that the studies carried out from year 2000 onwards lead us to conclude the greatest advance in CB techniques is the use of indicators such as the NPV and the IRR ( between $74.6 \%$ and $85 \%$, and between 75.6 $\%$ and $76.7 \%$ respectively) by large firms (Graham and Harvey 2001) and medium and small firms (Ryan and Ryan, 2002) from the USA, as also confirmed with $87 \%$ in large and medium-sized companies in the United Kingdom (Arnold and Hatzopulos, 2000) and 
in Australian companies with 94 \% (Truong, Partington, and Peat, 2008).

On the contrary, Brounen et al. (2004) conclude IRP is the most used variable by firms (between $50 \%$ and $69.2 \%$ ) while NPV and IRR come in second and third place respectively, similar to Hanaeda and Serita's (2014) finding in Japan. Authors Singh, et al. (2012) found that although IRR is the preferred technique (78.57\%), IRP is the second most used indicator (64.28 \%) by nonfinancial BSE 200 (Bombay Stock Exchange Index). Meanwhile, in their comparative study on the CB practices of Dutch and Chinese firms, Hermes et al. (2007) determined that the former choose NPV (89 \% of companies) and then IRP or Pay Back (PB) and IRR, while the latter first use IRR (89 \%), then IRP (84 $\%$ ) and finally NPV (49 \% of companies). The drawback of using IRP or PB is the time value of money is not included, and cash flows are also not taken into account after the investment has been recovered (Graham and Harvey, 2001; Bennouna, et al., 2010).

\subsection{Family businesses}

FBs, defined as those that are controlled by family (e.g., father, mother, sister, brother, son, daughter) where two or more directors are family-related and family members own or control at least $5 \%$ of shares with voting rights (Gómez- Mejía, Lazarra-Kintana, and Makri, 2003), are of great significance worldwide (Schulze, Lubatkin, Dino, and Buchholtz, 2003; Gómez-Mejía, et al. 2007), mainly in emerging economies in which they are considered a motor of the economy (Carney, 2005; Kachaner, Stalk, and Bloch, 2012). They are used as a unit of analysis because of how differently they behave in comparison with other organizational forms and how heterogeneous they are (Berrone, Cruz, and Gómez-Mejía, 2010; Chrisman, Chua, Pearson, and Barnett, 2012). Perhaps the most important FB characteristic concerns SEW, seen as the main interest within this type of businesses and the basis on which several decisions are made (GómezMejía et al., 2007; Berrone et al., 2010). This is the reason why, in an effort to guarantee SEW preservation -through maintaining their identity, the ability to exercise family control and influence, and perpetuating the family dynasty (Gomez-Mejia et al., 2007)-, these firms avoid either hiring staff outside the family (who may be better qualified) or resorting to external credits since this can lead to the loss of company control by the owner family and therefore compromise their SEW (Jones, Makri, and Gómez- Mejía, 2008).

\section{Methodology}

To achieve the research aims, the methodology takes a positivist-quantitative focus, for which a questionnaire was designed and applied to the firms in the sample. Data were taken from firms from the different economic subsectors from the Department of Antioquia which were registered in the Superintendence of Companies (3227), from which those meeting the following parameters for the period between 2010 and 2015 were selected: (1) Keeping then same business activity (as per CIIU code). (2) Firms that retained their size (large, medium or small), based on Law 905 of 2004 regulating Micro and SMEs. (3) Firms had to be reporting their financial statements for each and every year to the Superintendence of Companies. This resulted in a population of 898 firms, of which 11\% are large, $48.3 \%$ medium and $40.6 \%$ small.

Initially, the questionnaire was sent to the people in charge of evaluating the projects of the firms, which yielded only 9 correctly completed surveys (1\% of the sample). Subsequently, the remaining 889 were contacted by telephone, which allowed adding 173 correctly completed surveys (19.3\% of the sample), reaching a total sample of 182 usable surveys ( $20.3 \%$ of the contacted sample)

Following Graham and Harvey (2001), the questionnaire questions include variables such as viability indicators, discount rates, $\mathrm{CE}$ calculation, adjustments to the cost of capital and differentiation among some type of projects. Besides, in order to meet the objective regarding adjustment by size premium, the questionnaire inquires about the making of such adjustments in the CE, about the methodology used for calculating them (presenting, among other options, the models of Banz, 1981; Fama and French, 1993; Ibbotson, 2003, Pereiro and Galli, 2000) and 
Figure 1. Characterization of firms from the sample Project evaluation B. Classification by type of firms that evaluate their projects

\section{A. Project evaluation}

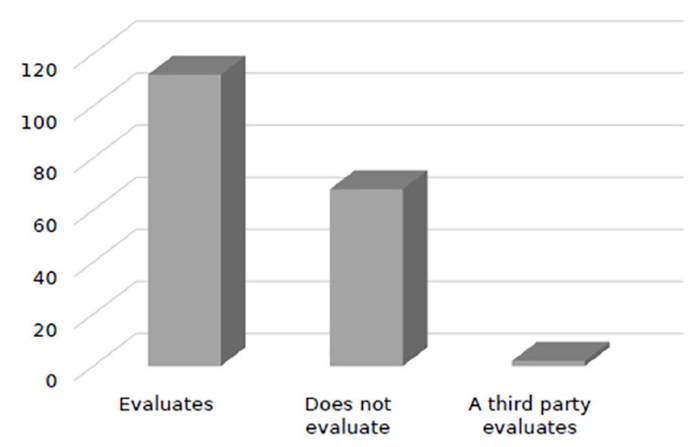

C. Firms by size and type of firms that evaluate their projects

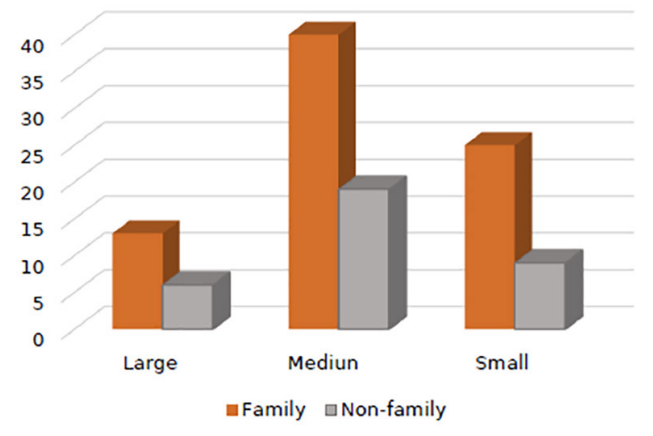

B.Classification by type of firms that evaluate their projects

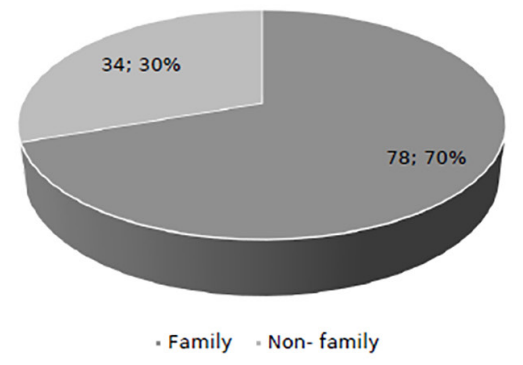

D. Classification of firms by project type and types of firms that evaluate their projects

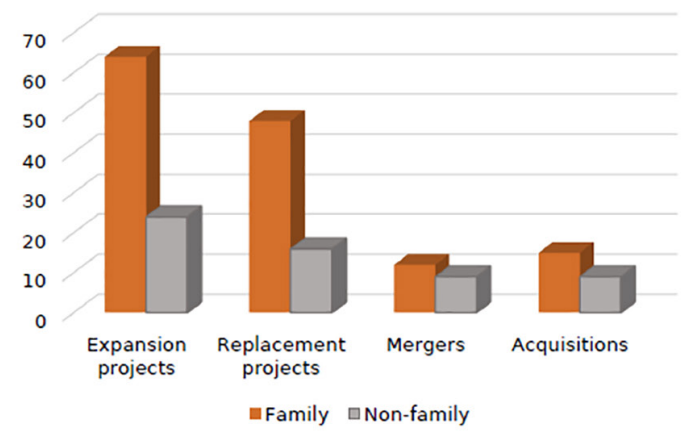

Source: Own elaboration from survey data of 182 firms.

about the value (or range of values) used as adjustment, differentiating between FB and NFB.

For the data analysis, the SPSS 25 software was used, allowing to create, as statistical technique, contingency tables and standardized residual and corrected standardized residual test, which enabled to analyze the existing relationship between categorical variables. Once standardized, the corrected standardized residuals follow a normal distribution. If they are greater or lower than 1.96 in absolute value, it indicates that there is a $95 \%$ reliability that the results are significant at a confidence level of 0.95 . Besides, in some relationships, control variables are used to observe the incidence of these variables in the relationship of the categorical variables and define the existence or not of spurious relationships. Listed firms or those from the financial sector were not included in the sample.

\section{Results}

A characterization of the sample was possible thanks to the statistics obtained from its data. It was found that $11 \%$ (20) out of the 182 firms surveyed are large, 54.4\% (99) are medium-sized and $34.6 \%$ (63) are small; $67.6 \%$ are FB and $32.4 \%$ are NFB. The sample was also characterized according to whether the firms evaluated their projects or not, as shown in Figure 1. In this sense, the preliminary findings raise the alarm on the way in which firms are making their investment decisions given that only $61.54 \%$ (112) of the 182 surveyed firms evaluate their projects (Figure 1A), and the majority are family businesses $(70 \%$, equivalent 
Table 3. Discount rates used to evaluate projects

\begin{tabular}{|c|c|c|c|c|c|c|c|c|c|c|c|c|c|c|c|}
\hline \multirow{3}{*}{ Type of business } & \multicolumn{12}{|c|}{ Project type } & \multicolumn{3}{|c|}{$\begin{array}{l}\text { Total use of } \\
\text { discount rate }\end{array}$} \\
\hline & \multicolumn{3}{|c|}{ Expansion (88) } & \multicolumn{3}{|c|}{$\begin{array}{c}\text { Replacement } \\
\text { (64) }\end{array}$} & \multicolumn{3}{|c|}{ Mergers (21) } & \multicolumn{3}{|c|}{$\begin{array}{c}\text { Acquisitions } \\
\text { (24) }\end{array}$} & & & \\
\hline & \multicolumn{3}{|c|}{ Firm } & \multicolumn{3}{|c|}{ Firm } & \multicolumn{3}{|c|}{ Firm } & \multicolumn{3}{|c|}{ Firm } & \multicolumn{3}{|c|}{ Firm } \\
\hline Family (78 firms) & $*$ & $* *$ & $* * *$ & $*$ & $* *$ & $* * *$ & $*$ & $* *$ & $* * *$ & $*$ & $* *$ & $* * *$ & $*$ & $* *$ & $* * *$ \\
\hline Cost of equity & 4 & 7 & 5 & 3 & 5 & 3 & 0 & 2 & 2 & 0 & 5 & 1 & 5 & 9 & 5 \\
\hline Does not use rate & 0 & 3 & 2 & 0 & 1 & 2 & 0 & 0 & 1 & 0 & 1 & 1 & 0 & 3 & 4 \\
\hline Intuitive rate & 0 & 9 & 4 & 0 & 6 & 5 & 0 & 1 & 3 & 0 & 2 & 0 & 0 & 9 & 7 \\
\hline Suggested rate & 1 & 3 & 1 & 1 & 3 & 1 & 1 & 0 & 0 & 0 & 0 & 0 & 2 & 4 & 1 \\
\hline WACC & 2 & 7 & 3 & 0 & 7 & 3 & 0 & 1 & 0 & 2 & 2 & 1 & 2 & 8 & 4 \\
\hline WACC - Cost of Equity & 4 & 7 & 2 & 2 & 3 & 3 & 0 & 1 & 0 & 0 & 0 & 0 & 4 & 7 & 4 \\
\hline \multicolumn{16}{|l|}{ Non-family (34 firms) } \\
\hline Cost of equity & 0 & 3 & 3 & 0 & 3 & 2 & 0 & 0 & 1 & 0 & 0 & 1 & 0 & 4 & 3 \\
\hline Does not use rate & 0 & 1 & 2 & 0 & 1 & 0 & 0 & 2 & 0 & 0 & 2 & 0 & 0 & 3 & 2 \\
\hline Intuitive rate & 0 & 2 & 0 & 0 & 1 & 0 & 0 & 0 & 0 & 0 & 1 & 0 & 0 & 2 & 0 \\
\hline Suggested rate & 3 & 1 & 0 & 0 & 1 & 0 & 0 & 0 & 1 & 3 & 0 & 0 & 3 & 2 & 1 \\
\hline WACC & 0 & 2 & 2 & 0 & 1 & 1 & 1 & 0 & 0 & 0 & 1 & 0 & 1 & 2 & 2 \\
\hline WACC - Cost of Equity & 1 & 3 & 1 & 2 & 3 & 1 & 1 & 3 & 0 & 1 & 0 & 0 & 2 & 6 & 1 \\
\hline
\end{tabular}

to 78 firms - Figure 1B). As expected, it is large firms (100\%, - Figure 1C) that perform their project evaluation most regularly. Additionally, expansion projects are the most evaluated type of projects by FBs (64, accounting for $82 \%$ of the projects evaluated - Figure 1D). The same characteristics are evidenced in the NFBs that conduct project evaluation (Figures 1C and 1D). It is worth noting that the majority of firms that do not evaluate their projects or whose projects are evaluated by a third party are SMEs (98.5\% of those that do not carry out project evaluation).

Regarding the discount rate ${ }^{3}$, on the whole firms mainly use CE (23.2\%), followed by WACC and CE (21.4\%) and finally by the use of WACC only (17\%), equivalent to 69 firms. When making comparisons based on business type, CE is most used by FBs (24.4\%) while $26.5 \%$ of NFBs use both WACC and CE.

On the other hand, it is highlighted that $11.6 \%$ of firms use a rate suggested by an expert, $10.7 \%$ do not use any discount rate and $16.1 \%$ use an intuitive rate. In this respect, $9 \%$ of FBs do not use a discount rate and $20.5 \%$ define it intuitively whereas a total of $20.6 \%$ of NFBs do not use one or define it intuitively.

Finally, if the analysis is performed based on project type, and overlooking business type, the rate suggested by an expert, CE, WACC or both are the most used as a discount rate in expansion and replacement projects (74 \% and $75 \%$ respectively), whereas intuitive rates or lack of a rate are most used for mergers and acquisitions. If company and project types are differentiated, FBs either make no use of rates or use intuitive rates more often than NFBs in three of the four types of projects (Table 3 ).

In parallel, a negative association relationship between large firms and the defining of the discount rate intuitively was found with the contingency tables as well as a positive association relationship between such firms and the definition of the discount rate on an expert's advice (Table 4).

3 The options were as follows: (i) cost of equity, (ii) WACC, (iii) WACC and cost of equity, (iv) intuitive rate, rate suggested by an expert and lack of rate use. 
Table 4. Relationship of the rate used as discount rate and firm size

\begin{tabular}{|c|c|c|c|c|c|c|}
\hline & & & \multicolumn{3}{|c|}{ Firm size } & \multirow{2}{*}{ Total } \\
\hline & & & Large & Large & Small & \\
\hline \multirow{6}{*}{$\begin{array}{l}\text { Discount rate } \\
\text { used }\end{array}$} & \multirow{3}{*}{ Intuitive rate } & $\mathrm{n}$ & 0 & 11 & 7 & 18 \\
\hline & & RT & -1.7 & 0.5 & 0.7 & \\
\hline & & RTC & -2.1 & 0.8 & 0.9 & \\
\hline & \multirow{3}{*}{ Suggested rate } & $\mathrm{n}$ & 5 & 6 & 2 & 13 \\
\hline & & RT & 1.9 & -0.3 & -1.0 & \\
\hline & & RTC & 2.2 & -0.5 & -1.2 & \\
\hline
\end{tabular}

Table 5. Models or rates used for calculating cost of equity

\begin{tabular}{|c|c|c|c|c|c|c|c|c|c|c|c|c|c|c|c|}
\hline \multirow{3}{*}{ Type of business } & \multicolumn{12}{|c|}{ Project type } & \multirow{2}{*}{\multicolumn{3}{|c|}{$\begin{array}{c}\text { Total models } \\
\text { used }\end{array}$}} \\
\hline & \multicolumn{3}{|c|}{$\begin{array}{c}\text { Expansion } \\
\text { (56) }\end{array}$} & \multicolumn{3}{|c|}{$\begin{array}{c}\text { Replacement } \\
\text { (42) }\end{array}$} & \multicolumn{3}{|c|}{ Mergers (12) } & \multicolumn{3}{|c|}{$\begin{array}{l}\text { Acquisitions } \\
\text { (14) }\end{array}$} & & & \\
\hline & \multicolumn{3}{|c|}{ Firm } & \multicolumn{3}{|c|}{ Firm } & \multicolumn{3}{|c|}{ Firm } & \multicolumn{3}{|c|}{ Firm } & \multicolumn{3}{|c|}{ Firm } \\
\hline Family (48 firms) & $*$ & $* *$ & $* * *$ & $*$ & $* *$ & $* * *$ & $*$ & $* *$ & $* * *$ & $*$ & $* *$ & $* * *$ & $*$ & $* *$ & $* * *$ \\
\hline CAPM & 6 & 3 & 0 & 1 & 3 & 1 & 0 & 2 & 0 & 2 & 2 & 0 & 6 & 3 & 1 \\
\hline Industry's profitability (IP) & 1 & 7 & 4 & 2 & 2 & 3 & 0 & 1 & 2 & 0 & 4 & 0 & 2 & 9 & 5 \\
\hline Defined intuitively & 1 & 3 & 1 & 1 & 3 & 1 & 0 & 0 & 0 & 0 & 0 & 0 & 1 & 3 & 2 \\
\hline Established by the firm & 1 & 6 & 2 & 1 & 5 & 1 & 0 & 1 & 0 & 0 & 1 & 2 & 1 & 6 & 2 \\
\hline IP - CAPM & 1 & 0 & 0 & 0 & 0 & 0 & 0 & 0 & 0 & 0 & 0 & 0 & 1 & 0 & 0 \\
\hline IP-Established by the firm & 0 & 1 & 2 & 0 & 1 & 2 & 0 & 0 & 0 & 0 & 0 & 0 & 0 & 1 & 2 \\
\hline IP-Intuitive & 0 & 1 & 1 & 0 & 1 & 1 & 0 & 0 & 0 & 0 & 0 & 0 & 0 & 2 & 1 \\
\hline \multicolumn{16}{|l|}{ Non-family (21 firms) } \\
\hline CAPM & 0 & 1 & 0 & 0 & 1 & 0 & 0 & 1 & 0 & 0 & 0 & 0 & 0 & 2 & 0 \\
\hline Industry's profitability (IP) & 1 & 2 & 2 & 1 & 3 & 1 & 1 & 1 & 0 & 1 & 1 & 0 & 1 & 5 & 2 \\
\hline Defined intuitively & 0 & 0 & 2 & 0 & 0 & 1 & 0 & 0 & 0 & 0 & 0 & 0 & 0 & 0 & 2 \\
\hline Established by the firm & 0 & 3 & 2 & 0 & 2 & 2 & 1 & 0 & 1 & 0 & 0 & 1 & 1 & 3 & 2 \\
\hline IP - CAPM & 0 & 2 & 0 & 1 & 1 & 0 & 0 & 1 & 0 & 0 & 0 & 0 & 1 & 2 & 0 \\
\hline IP-Established by the firm & 0 & 0 & 0 & 0 & 0 & 0 & 0 & 0 & 0 & 0 & 0 & 0 & 0 & 0 & 0 \\
\hline IP-Intuitive & 0 & 0 & 0 & 0 & 0 & 0 & 0 & 0 & 0 & 0 & 0 & 0 & 0 & 0 & 0 \\
\hline
\end{tabular}

In respect to how $\mathrm{CE}^{4}$ is calculated by firms (as shown in Table 5), in general terms firms first use industry's profitability -IP(35\%; $13 \%$ of which are large, 56\% mediumsized and $31 \%$ small), followed by a method established by the firm itself $(22 \% ; 11 \%$ of which are large, $67 \%$ medium-sized and $22 \%$ small) and thirdly the CAPM (17\%; $60 \%$ of which are large, 30\% medium-sized, and 10\% small).

When differentiating by company type, although both FBs and NFBs follow the general trend, mainly using IP (33\% and 38\%, respectively), CAPM is the second most used rate by FBs (21\%) whereas NFBs use a model

4 Only 69 firms were selected: 48 family businesses and 21 Non-family businesses that used cost of equity, WACC or both rates as discount rate. This makes perfect sense given that when the firms were asked how they calculated the WACC, they indicated they consider both the cost of external debt and what they expect to raise out of their own resources. 


\begin{tabular}{|c|c|c|c|c|c|c|c|c|c|c|}
\hline \multirow{2}{*}{\multicolumn{4}{|c|}{ Type of business }} & \multicolumn{7}{|c|}{ Methodology for calculating cost of equity } \\
\hline & & & & CAPM & $\begin{array}{l}\text { Calculated } \\
\text { from IP }\end{array}$ & Intuitive & $\begin{array}{l}\text { Established } \\
\text { by the firm }\end{array}$ & IP-CAPM & $\begin{array}{l}\text { IP- } \\
\text { established } \\
\text { by the firm }\end{array}$ & $\begin{array}{c}\text { IP- } \\
\text { Intuitive }\end{array}$ \\
\hline \multirow{3}{*}{ Family } & \multirow{3}{*}{ Size } & \multirow{3}{*}{ Large } & $\mathrm{n}$ & 6 & 2 & 1 & 1 & 1 & 0 & 0 \\
\hline & & & $\mathrm{RT}$ & 2.4 & -0.9 & -0.3 & -0.7 & 1.6 & -0.8 & -0.8 \\
\hline & & & RTC & 3.1 & -1.2 & -0.4 & -0.9 & 1.9 & -1.0 & -1.0 \\
\hline \multirow{3}{*}{$\begin{array}{l}\text { Non- } \\
\text { family }\end{array}$} & \multirow{3}{*}{ Size } & \multirow{3}{*}{ Small } & $\mathrm{n}$ & 0 & 2 & 2 & 2 & 0 & & \\
\hline & & & RT & -0.8 & -0.2 & 1.9 & 0.2 & -0.9 & & \\
\hline & & & RTC & -0.9 & -0.3 & 2.4 & 0.3 & -1.2 & & \\
\hline \multicolumn{11}{|c|}{ Note. The relationships with the rest of the size categories were identified but are not presented in this table because they are not significant. } \\
\hline \multicolumn{11}{|c|}{ Source: Own elaboration with research data. } \\
\hline
\end{tabular}

established by the firm (29\%) as a second alternative to calculating CE.

In addition, a positive association relationship is observed between firm size and the use of the CAPM model as per the contingency tables; in fact, this association improves when the Business Type is introduced as a control variable, specifically for FBs. Similarly, a positive relationship was found between small firms and the use of intuitive rates to define CE (Table 6).

Conversely, only one medium-sized NFB includes it. 6 out of these 9 firms where a size premium is included calculate CE based on the CAPM model, and the addition of such premium is most frequently found in large firms' expansion projects (Table 7).

In this way, through contingency tables, it was possible to establish a positive association relationship between firm size and size adjustment, and between the latter and the CAPM model (Tables 8 and 9).

A finding that further shows the gap between theory and practice is the explanation that respondents provide when inquired about the reason for not including the size premium. 43 firms (62.3\%) assert they do not know it and 10 firms (6.9\%) acknowledge they indeed know the concept yet do not know how to calculate it.

As for the model or method for calculating the size premium and its value, the most used is intuition (56\%) while Fama and French' model (1993), Ibbotson' model (2003) and the calculation based on models taken from financial institutions are all at the same level (22.2\%).

Although large firms using the CAPM are mainly the ones adjusting for size, only one of them makes use of a stylized model to define it, while 6 of the 9 companies that adjust for size (those using the CAPM), make an adjustment that ranges between $1 \%$ and $5 \%$..

It is worth mentioning that 12 of the 112 firms that carry out project evaluations but define the discount rate intuitively (8 firms), or through an expert (4 firms), usually adjust this rate for size. However, 5 of the respondents argue not to know what the value used as premium is, while the value ranges between $1 \%$ and $10 \%$ at the remaining 7 firms.

In general terms, with regard to the use and calculation of indicators for evaluating project viability ${ }^{5}$, the most widely used is CBR followed by NPV and IRR (64.3\%, 60\% and $53 \%$ of the projects, respectively); when differentiating by firm type, NFBs mainly use NPV and IRR (67.7\% each), which is also true for each project type, except for mergers where CBR is used more (100\%). In addition, it was possible to establish a significant, positive association relationship between IRR and NFB; this may be due to the fact that these firms are likely to have more skilled staff in these areas than FBs, where relatives

5 The research investigates NPV, IRR, IRP, MIRR, Cost-Benefit Ratio (CBR), Economic Value Added (EVA), Market Value Added (MVA), among others. 

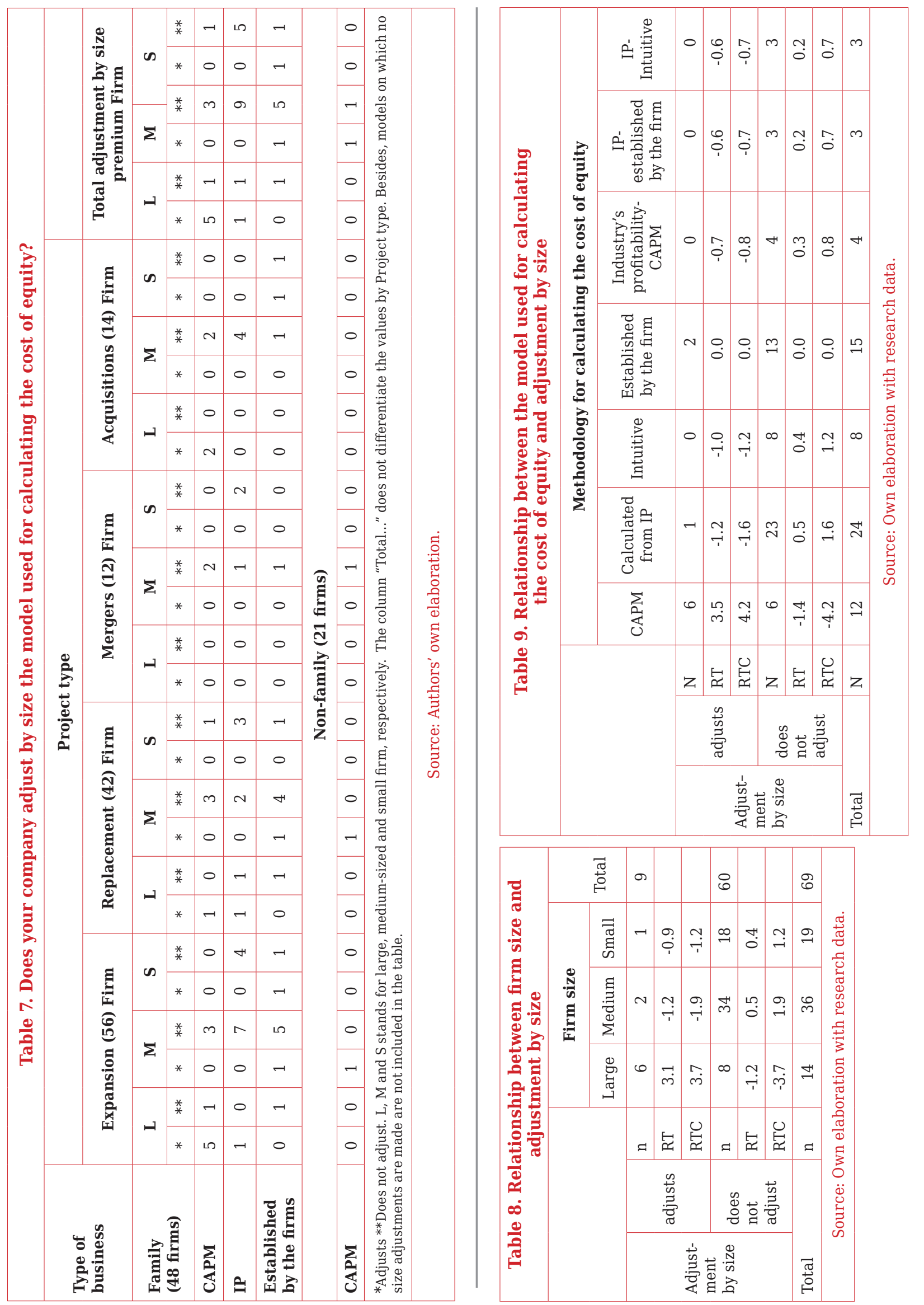

https://doi.org/10.25100/cdea.v36i67.7896 
are usually hired regardless of whether they possess the skills required.

In turn, CBR is more often used (in different project types, except for expansion projects) by FBs $(60.3 \%)$, followed by the use of NPV and IRP (56.4\% each). A similar scenario emerges when these firms are categorized by size, disregarding project type. Finally, it was found that $10.7 \%$ of the firms calculate the indicators without taking into account the time value of money. (Tables 10 and 11).

\section{Discussion}

The informal approach adopted by Colombian companies in the use of $\mathrm{CB}$ techniques, for example, the lack of use of a discount rate or calculating it intuitively, leads to their projects either being overvalued or undervalued, resulting in missed investment opportunities or, in the worst case, exposing firms to financial losses. However, defining $\mathrm{CB}$ through more objective techniques also implies risks. For example, calculating CB from Market returns exposes investors to using inadequate values as the discount rate, and therefore to possible financial losses, since the information available in Colombia is not enough, is not of quality, or is not disaggregated to enable the use of a CB proxy for most of the different economic activities developed in the country.

Under this scenario, one might think using the CAPM to calculate CE would be a better option; however, despite its widespread use, if implemented in emerging economies in its original version, it would lead to projects being overvalued since it has been designed for developed economies where companies are much larger. In this respect, not adjusting said model for additional risks, such as size, would translate into those risks being undervalued and, consequently, to overestimating the added value of projects. However, it is reassuring to see that the percentage of companies that add the size premium in Colombia is similar to that of the other economies.

But making the adjustment is not enough. In this study, it was concluded firms may be overestimating or undervaluing their projects by determining size adjustment intuitively. However, most of the models employed for this purpose use publicly listed companies which, interestingly enough, are large companies from developed economies (indicating that the size issue is not only a concern for small companies or emerging economies). Along this vein, it is considered more appropriate for companies to use models such as Pereiro and Galli's (2000) for calculating $\mathrm{CE}$ and the size premium since it is built based on companies that are not publicly traded, like most Colombian firms, and whose characteristics resemble Colombian ones.

On the other hand, according to the evidence found in this study, it is worth noting the adjustment is made by large companies mainly, which is contradictory given that SMEs are the firms facing the greatest risks due to their size (Fama and French, 1993; Pereiro and Galli, 2000).

Finally, the preferential use of indicators such as CBR and IRR by family SMEs shows the lack of awareness of the benefits that the implementation of adequate techniques in their investment decisions can generate for the growth and stability of the company. Nevertheless, FBs cannot be judged lightly. Their concern for preserving SEW over financial objectives may provide support for the level of informality in CB practices: in adopting an altruistic stance, they prefer to hire relatives (who may not possess the financial knowledge) rather than qualified external employees, which increases SEW but can affect performance. The fact that $\mathrm{CE}$ is used more by FBs as a discount rate actually provides an explanation for their concerns about SEW; they hardly resort to external credits or participate in mergers and acquisitions in an attempt to keep control of the company.

This study is not without limitations. The data cannot be generalized due to the size of the sample, so future studies could improve on this aspect of the research in addition to carrying out the survey in person, if possible, in order to avoid likely biases in the results. Finally, since causal analyses are not determined in this investigation, future research could examine the effect the use of the different $\mathrm{CB}$ practices has on performance, and conduct longitudinal 


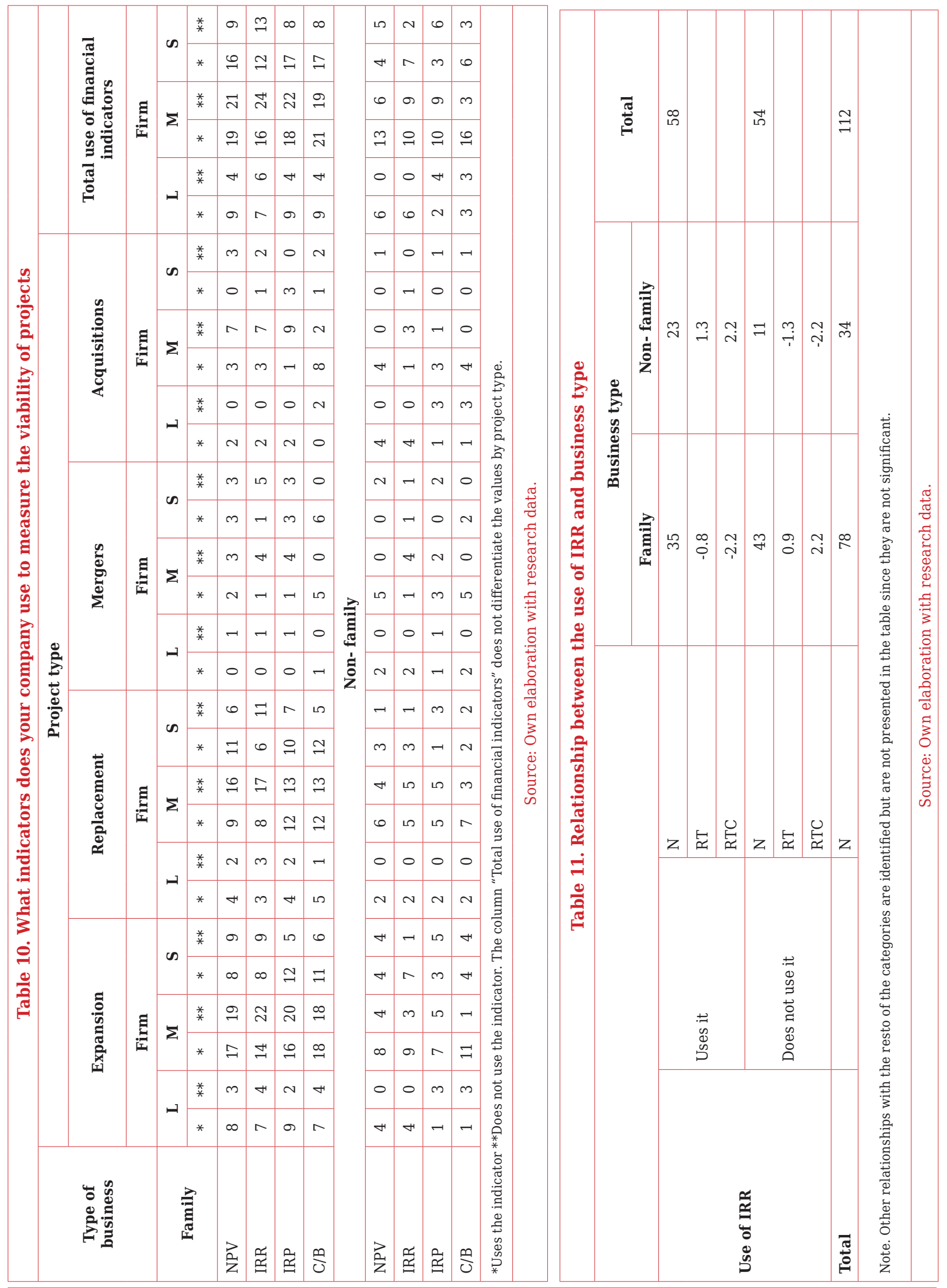


analyses that account for the progress in the techniques used in CB.

\section{Conclusions}

The aim of this research is to generate new evidence on the $\mathrm{CB}$ practices of Colombian FBs and NFBs so that the quality of the discussion and research in this field in emerging economies be enhanced; new evidence which can be contrasted with the results obtained by previous studies conducted decades earlier is provided.

In this sense, the use of discount rates within CB techniques shows the gap between theory and practice given that they are either not used or calculated intuitively by a significant percentage of the companies in the simple. This gap is more evident in terms of the use of models such as the CAPM and the WACC, widely disseminated from classrooms, guidebooks and research studies - since the number of (mainly large) firms using them in Colombia today is similar to that indicated by Brigham (1975) 45 years before and is far below Graham and Harvey's (2001) findings from almost 20 years earlier. As expected, SMEs are the most informal in the use of discount rates and FBs are the firms which resort the most to defining these rates intuitively or simply not using them. Interestingly, FBs are the ones which utilize the CAPM the most when determining the CE model; in addition, expansion and replacement projects are the most rigorously evaluated and either no discount rate or more intuitive rates are used for projects such as mergers or acquisitions.

Size adjustment to CE, a procedure recommended by several authors, is a scarcely observed practice in Colombia, and large FBs carry it out the most in their expansion projects. Despite this, the percentage of firms that adjust for size in Colombia is on par with that of other economies. However, informality prevails when determining the value of said adjustment: most of firms calculating it do so intuitively, evidencing the gap between theory and practice. The fact that most of the companies not implementing the adjustment claim not to have knowledge about the subject, or knowing about it but not being able to calculate the adjustment, serves as confirmation for the above.

The value of the size premium employed by Colombian companies which use the CAPM to define CE is very close to the values recommended by authors such as Rubio (1988) and Ibbotson Associates (2003) for developed economies, which calls for a review when considering the size of Colombian companies.

FBs carry out the least sophisticated CB process in terms of the type of indicators to determine project viability and the way to calculate them, so they overlook the time value of money. Many of the evaluations do not include a discount rate, and although this work identifies NPV as one of the most used techniques in Colombia, it is worrying that the percentage of use of this indicator is far below the percentage of use found almost 20 years ago by Graham and Harvey (2001). Furthermore, the preference for the use of indicators such as CBR and IRR by SMEs shows the financial ignorance of those in charge of project evaluation.

\section{Conflicts of interest}

The authors declare no conflicts of interest.

\section{Funding sources}

This research was funded by the Research and Consulting Center -CIC- of Universidad de Antioquia (Identification and analysis of size premium calculation in defining the discount rate for project evaluation, the case of Colombia) and is conducted by researcher professors of the Faculty of Economic Sciences of the University and administrative staff from the financial laboratory of the Faculty.

\section{References}

Arnold, G. C., \& Hatzopoulos, P. D. (2000). The theory-practice gap in capital budgeting: Evidence from the United Kingdom. Journal of Business Finance and Accounting, 27(5-6), 603626. https://doi.org/10.1111/1468-5957.00327

Asness, C., Frazzini, A., Israel, R., Moskowitz, T. J., \& Pedersen, L. H. (2018). Size matters, if 
you control your junk. Journal of Financial Economics, 129(3), 479-509. https://doi. org/10.1016/j.jfineco.2018.05.006

Banz, R. W. (1981). The relationship between return and market value of common stocks. Journal of Financial Economics, 9(1), 3-18. https://doi.org/10.1016/0304-405X(81)90018-0

Barry, C. B., Goldreyer, E., Lockwood, L., \& Rodríguez, M. (2002). Robustness of size and value effects in emerging equity markets, 19852000. Emerging Markets Review, 3(1), 1-30. https://doi.org/10.1016/S1566-0141(01)00028-0

Batra, R., \& Verma,S. (2017). Capital budgeting practices in Indian companies. Management Review, 29(1), 29-44. https://doi.org/10.1016/j. iimb.2017.02.001

Bennouna, K., Meredith, G. G., \& Marchant, T. (2010). Improved capital budgeting decision making: Evidence from Canada. Management Decision, 48(2), 225-247. https://doi. org/10.1108/00251741011022590

Berrone, P., Cruz, C., Gómez-Mejía, L.R., \& Larraza-Kintana, M. (2010). "Socioemotional Wealth and Corparate Responses to Institutional Pressures: Do family Controlled firms Pollute Less?". Administrative Science Quarterly, 55(1), 82-113. https://doi.org/10.2189/ asqu.2010.55.1.82

Block, S. B (1977). Capital budgeting techniques used by small business firms in the 1990s. The Engineering Economist,42(4), 289-302. https:/l doi.org/10.1080/00137919708903184

Block, S. B (1999). A Study of Financial Analysts: Practice and Theory. Financial Analysts Journal, 55(4), 86-92. https://doi.org/10.2469/faj.v55. $\underline{\mathrm{n} 4.2288}$

Brickley. S.Z. (2006). Managerial Economics and Organizational Architecture, (3 ${ }^{\text {rd }}$ ed.). China: McGraw-Hill.

Brigham, E. F. (1975). Hurdle Rates for Screening Capital Expenditure Proposals. Financial Management, 4(3), 17-26. https://doi. org/10.2307/3665186

Brigham, E. F., \& Ehrhardt, M. C. (2002). Financial Management: Theory and Practice $\left(10^{\text {th }}\right.$ ed.). Ohio, USA: Thomson/South-Western.

Brounen, D., De Jong A., \& Koedijk, K. (2004). Corporate finance in Europe: confronting theory with practice. Financial Management, 33, 71-101. Retrieved from https://ep.eur.nl/ handle/1765/1111
Bruner, R. F., Eades K. M., Harris, R. S., \& Higgins, R. C. (1998). Best practices in estimating the cost of capital: Survey and synthesis. Financial Practice and Education, 8, 13-28. Retrieved from https://ntrda.me/2XVKI1G

Carney, M. (2005). Corporate governance and competitive advantage in familycontrolled firms. Entrepreneurship Theory and Practice, 29(3), 249-265. https://doi. org/10.1111\%2Fj.1540-6520.2005.00081.x

Chan, K. C., Chen, N. F., \& Hsieh, D. (1985). An exploratory investigation of the firm size effect. Journal of Financial Economics, 14(3), 451-471. https://doi.org/10.1016/0304-405X(85)90008-X

Chrisman, J. J., Chua, J. H., Pearson, A. W., \& Barnett, T. (2012). Family Involvement, Family Influence, and Family-Centered Non-Economic Goals in Small Firms. Entrepreneurship Theory and Practice, 36(2), 267-293. https://doi. org/10.1111/j.1540-6520.2010.00407.x

Damodaran, A. (2003). Measuring Company Exposure to Country Risk: Theory and Practice. Working paper. New York University. http:// dx.doi.org/10.2139/ssrn.889388

Dayananda, D., Irons, R., Harrison, S., Herbohn, J., y Rowland, P. (2002). Capital Budgeting: Financial Appraisal of Investment Projects, Edinburgh: Cambridge University Press. Retrieved from https://bit.ly/2WhBeNF

Dean, J. (1952). Capital Budgeting: Top Management Policy on Plant, Equipment and Product. Southern Economic Journal, 19(1), 109-111. Retrieved from https://www.jstor.org/ stable/1053981

Dickson, P.R. y Giglierano, J.J. (1986). Missing the Boat and Sinking the Boat: A Conceptual Model of Entrepreneurial risk. Journal of Marketing, 50 (3), 58-70. https://doi. org/10.1177/002224298605000305

Estrada, J. (2007). Mean-semivariance behavior: Downside risk and capital asset pricing. International Review of Economics and Finance, 16(2), 169-185. $\quad$ https://doi.org/10.1016/j. iref.2005.03.003

Fama, E. F. y French, K. R. (1992). The CrossSection of Expected Stock Returns. The Journal of Finance, 47(2),427-465. https://doi. org/10.1111/j.1540-6261.1992.tb04398.x

Fama, E. F. y French, K. R. (1993). Common risk factors in the returns on stocks and bonds. Journal of Financial Economics, 33(1), pp. 3-56. https://doi.org/10.1016/0304-405X(93)90023-5 
Fama, E. F. y French, K. R. (1998). Value versus Growth: The International Evidence. The Journal of Finance, 53(6), 1975-1999. https://doi. org/10.1111/0022-1082.00080

Fama, E. F. y French, K. R. (2015). A five-factor asset pricing model. Journal of Financial Economics, 116(1), 1-22. https://doi.org/10.1016/j. jfineco.2014.10.010

Family Firm Institute. (2014). Global Data Points. Retrieved from https://bit.ly/1WyWigc

Gitman, L. J., y Forrester, J. R. (1977). A Survey of Capital Budgeting Techniques Used by Major U.S. Firms. Financial Management, 6(3), 66-71. Retrieved from http://www.jstor.org/ stable/3665258

Gómez- Mejía, L. R., Lazarra-Kintana, M., \& Makri, M. (2003). "The Determinants of Executive Compensation in Family-Controlled Public Corporations". The Academy of Management Journal, 46(2), 226-237. https://doi. org/10.5465/30040616

Gómez-Mejía, L. R., Haynes, K. T., NúñezNickel, M., Jacobson, K., \& Moyano-Fuentes, J. (2007). Socioemotional Wealth and Business Risks in Family-controlled Firms: Evidence from Spanish Olive Oil Mills. Administrative Science Quarterly, 52(1), 106-137. https://doi. org/10.2189/asqu.52.1.106

Graham, J. R., \& Harvey, C. R. (2001). The theory and practice of corporate finance: evidence from the field. Journal of Financial Economics, 60(2-3), 187-243. $\quad$ https://doi.org/10.1016/ $\underline{\mathrm{S} 0304-405 \mathrm{X}(01) 00044-7}$

Hanaeda, H., \& Serita, T. (2014). Capital Budgeting Practices: Evidence from Japan. Retrieved from http://dx.doi.org/10.2139/ssrn.2312264

Hermes, N., Smid, P., \& Yao, L. (2007). Capital budgeting practices: A comparative study of the Netherlands and China. International Business Review, 16(5), 630-654. https://doi.org/10.1016/j.ibusrev.2007.05.002

Hou, K., \& van Dijk, M. A. (2018). Resurrecting the size effect: Firm size, profitability shocks, and expected stock returns. Retrieved from http:// dx.doi.org/10.2139/ssrn.1005664

Ibbotson Associates. (2003). Stocks, Bonds, Bills and Inflation 2003 Yearbook. Chicago, USA: Valuation Edition, Ibbotson Associates.

Jones, C. D., Makri, M. , \& Gómez-Mejia, L. R. (2008). Affiliate directors and perceived risk bearing in publicly traded, family-controlled firms: the case of diversification. Entrepreneurship
Theory and Practice, 32(6), 1007-1026. https:// doi.org/10.1111/j.1540-6520.2008.00269.x

Bloch, A. Kachaner, N., \& Stalk, G. (2012). What you can learn from family business. Harvard Business Review, 90(11), 102-106. Retrieved from https://hal-hec.archives-ouvertes.fr/ hal-00743569

Kengatharan, L. (2018). Capital Budgeting Theory and Practice: A review and agenda for future research. American Journal of economics and business management. 1(1), 20-53. https://doi. org/https://doi.org/10.31150/ajebm.v1i1.5

Lessard, D. R. (1996). Incorporating Country Risk in the Valuation of Offshore Projects. Journal of Applied Corporate Finance, 9(3), 52-63. https:// doi.org/10.1111/j.1745-6622.1996.tb00298.x

Maquieira, C. P., Preve, L. A., \& Sarria-Allende, V. (2012). Theory and practice of corporate finance: Evidence and distinctive features in Latin America. Emerging Markets Review, 13(2), 118-148. $\quad$ https://doi.org/10.1016/j. ememar.2011.11.001

Maroyi, V., \& Poll, H. M. (2012). A survey of capital budgeting techniques used by listed mining companies in South Africa. African Journal of business management, 6(32), 9279-9292. https://doi.org/10.5897/AJBM12.747

Nurullah, M., \& Kengatharan, L. (2015). Capital budgeting practices: evidence from Sri Lanka. Journal of Advances in Management Research, 12(1), 55-82. https://doi.org/10.1108/ JAMR-01-2014-0004

Pereiro, L. E., y Galli, M. (2000). La Determinación Del Costo Del Capital En La Valuación De Empresas De Capital Cerrado: Una Guía Práctica. Recuperado de http://marcelodelfino. net/files/paperwacc.pdf

Perlitz, M., Peske, T., \& Schrank, R. (1999). Real optionsvaluation : thenewfrontierin R\&Dproject evaluation? R\&D Management, 29(3), 255-269. https://doi.org/10.1111/1467-9310.00135

Rigopoulos, G. (2015). A review on Real Options utilization in Capital Budgeting practice. International Journal of Information, Business and Management, 7(2), 1-16. Retrieved from https://bit.ly/2VGRVVI

Rouwenhorst, K. G. (1999). Local return factors and turnover in emerging stock markets. Journal of Finance, 54(4), 1439-1464. https://doi. org/10.1111/0022-1082.00151

Rubio, G. (1988). Further international evidence on asset pricing. The case of the 
Spanish capitalmarket.Journal of Banking and Finance, 12(2), 221-242. https://doi. org/10.1016/0378-4266(88)90037-4

Ryan, P. A., \& Ryan, G. P. (2002). Capital Budgeting Practices of Fortune 1000 Firms: How Have Things Changed? Journal of Business \& Management, 8(4), 355-364. Retrieved from https://bit.ly/2WektTP

Sharpe, W. F. (1964). Capital asset prices: A theory of market equilibrium under conditions of risk. The Journal of Finance, 19(3), 425-442. https:/l doi.org/10.1111/j.1540-6261.1964.tb02865.x

Schulze,W. S., Lubatkin, M H., \& Dino, R. N. (2003). Exploring the Agency Consequences of Ownership Dispersion among the Directors of Private Family Firms. The Academy of Management Journal, 46(2), 179-194. https://doi. org/10.5465/30040613
Singh, S., Jain, P. K., \& Yadav, S. S. (2012). Capital budgeting decisions: evidence from India. Journal of Advances in Management Research, 9(1), 96-112. https://doi. org/10.1108/09727981211225671

Truong, G., Partington, G., \& Peat, M. (2008). Cost-of-Capital Estimation and CapitalBudgeting Practice in Australia. Australian Journal of Management, 33(1), 95-121. https:// doi.org/10.1177/031289620803300106

Van Dijk, M. A. (2011). Is size dead? A review of the size effect in equity returns. Journal of Banking and Finance, 35(12), 3263-3274. https:// doi.org/10.1016/j.jbankfin.2011.05.009

Verbeeten, F. H. M. (2006). Do organizations adopt sophisticated capital budgeting practices to deal with uncertainty in the investment decision?: A research note. Management Accounting Research, 17(1), 106-120. https://doi. org/10.1016/j.mar.2005.07.002

How to cite this paper?

Reina Gutiérrez, W., Moscoso Escobar, J., \& Montoya González, C. (2020). Adjustment by size effect on the cost of equity: Pending practice in capital budget in Colombia. Cuadernos de Administración, 36(67), $126-142$. https://doi.org/10.25100/cdea.v36i67.7896

Cuadernos de Administración journal by Universidad del Valle is under licence Creative Commons ReconocimientoNoComercial-SinObrasDerivadas 4.0. Based in http://cuadernosdeadministracion.univalle.edu.co/ 